To cite this Article: M.A. Poutanen, S. Koski (2016) THE NOSTALGIC WOMEN - THE BLOG THAT WAS AWARDED WITH THE ANNUAL AWARD IN MUSEUM PEDAGOGY 2016, ICERI2016 Proceedings, pp. 2447-2450.

DOI: $10.21125 /$ iceri.2016.0153

URL: https://library.iated.org/view/POUTANEN2016NOS 


\title{
THE NOSTALGIC WOMEN - THE BLOG THAT WAS AWARDED WITH THE ANNUAL AWARD IN MUSEUM PEDAGOGY 2016
}

\author{
Marjo Poutanen ${ }^{1}$, Susanna Koski ${ }^{2}$ \\ ${ }^{1}$ Laurea University of Applied Sciences (FINLAND) \\ ${ }^{2}$ The Lotta Museum (FINLAND)
}

\begin{abstract}
In this paper we present the Nostalgic Women project, a participative project which was given the Annual Award in Museum Pedagogy 2016. In autumn 2015, 45 students from the Bachelor of Beauty and Cosmetics Degree launched a cooperative project with The Lotta Museum and Keuda Vocational College beautician students as part of their studies. The project was based on Learning by Developing $(\mathrm{LbD})$ pedagogy where students' learning is connected to authentic development projects that are rooted in the world of work. The Lotta Museum is a professionally run specialist museum that records and documents the history of the Lotta Svärd organization and studies the volunteer work of women as part of the history of Finland. The project included workshop activities, on the basis of which the students were able to participate in the Museum's content and event production. The main output of the project was a blog 'Nostalgic Women'. Beauty and Cosmetics students produced 25 blog posts which combined cosmetic chemistry, wellbeing and culture during the 1930s and 1940s. The blog posts were published in 2016.
\end{abstract}

The special feature of the project was that an atypical target group, the students, started to create content based on their own vocational know-how for the already existing target group of the Museum. Through the content production, the Beauty and Cosmetics students were able to present their professional skills to the general public and popularize the science behind cosmetics and cosmetic products. The content generated by the students has, without exception, received plenty of positive feedback. The blog has a well-established readership. According to the students' feedback, the participative way of working and multi-professional collaboration was very useful and gave them more knowledge and experience of working life.

The Finnish Association for Museum Education, Pedaali, granted the Annual Award in Museum Pedagogy 2016 to the Nostalgic Women project. Pedaali's board viewed the project as representing a new approach of engaging audiences and a new way of making museums more accessible. Collaboration with educational institutions has helped to make the Lotta Museum more appealing to young audiences, which are considered to be a challenging target group, and the project has also demonstrated that the past is still relevant today. At the same time, the Lotta Museum has been able to present its themes on a contemporary platform, to provide it with a broader context and open it to wider audiences. The project has also made the museum and the Bachelor of Beauty and Cosmetics Degree more widely known.

Keywords: Blog, Museum education, The Bachelor of Beauty and Cosmetics, The Lotta Museum, Participative project.

\section{INTRODUCTION}

The Lotta Museum, and a group of Bachelor of Beauty and Cosmetics students from Laurea University of Applied Sciences and beautician students from Keuda Vocational College launched a cooperative project in autumn 2015. The project included workshop activities, on the basis of which the students were able to participate in the Museum's content and event production. The main output of the project was a blog named Nostalgic Women [1].

Laurea University of Applied Sciences is a multidisciplinary university operating in Southern Finland with approximately 8000 students and 550 staff members. Laurea is the only university in Finland to offer Bachelor of Beauty and Cosmetics studies. The Bachelor's Degree in Beauty and Cosmetics consists of 210 credits usually completed in 3.5 years. About 45 students start their studies annually to become experts in the beauty and cosmetics field. [2]

The degree programme in Beauty and Cosmetics combines competences on cosmetic products and raw materials while highlighting marketing and business competence. Communication, information 
technology and language skills are also important in the studies. A developmental approach is necessary for this rapidly changing and expanding sector. Laurea's learning concept is embodied in the Learning by Developing model, which has received awards from the Finnish Higher Education Evaluation Council. The learning objective is developing competence, which is visible as new ways and means of working, and which allows for renewal of the labour market and the field. Learning by Developing takes place in workplace-oriented projects in which students, lecturers, workplace experts and customers work together to develop innovative solutions.[2]

The aim of the Degree Programme in Beauty and Cosmetics is to provide the necessary skills to develop services, products and business activities in the cosmetic sector and to increase related knowledge. Laurea University of Applied Sciences is a well-known University collaborating in the Helsinki metropolitan area. Students work closely with companies and regional partners through projects and study units are linked closely to working life.

The Lotta Museum is a professionally run specialist museum that records and documents the history of the Lotta Svärd organization and studies the volunteer work of women as part of the history of Finland. The Museum is maintained by the Lotta Svärd Foundation and it was opened to the public in 1996. [3]

Lotta Svärd was a Finnish voluntary auxiliary paramilitary organisation for women. Formed originally in 1918 , it had a large membership undertaking volunteer social work in the 1920s and 1930s. During the Second World War, it mobilized to replace men conscripted into the army. It served in hospitals, at air raid warning positions, and other auxiliary tasks in close cooperation with the army. The women were officially unarmed except for the antiaircraft battery in 1944. The organisation was banned due to Russian demands by the government after the war.

\section{METHODOLOGY}

In the autumn of 2015, a group of Bachelor Degree of Beauty and Cosmetics students from Laurea University of Applied Sciences started the course on Ingredients of a Cosmetics Product by Their Functions. An integral part of the course was a collaborative project with The Lotta Museum, a regional partner of Laurea. The course, 5 credits, comprised of studies about cosmetic ingredients. The aim was that after the course the student would be able to recognize the most common ingredients in a cosmetics product and their most essential functions. Another aim was to recognize the link between the properties of a cosmetics product and the ingredients' chemical consistency. Another aim was that the student could use this knowledge to combine the information about the components of the cosmetic products and transform it into a consumer-friendly form, which was the aim of this collaborative project.

The students were not initially familiar with the history of women in war. In this collaborative project the students were first introduced to the Lotta Svärd organisation and the Lotta Museum before they started the project in groups. Video presentations about the Museum, pictures, accessories, clothes and magazines presented the life in the 1930s and 1940s and during the war. The main exhibition of the Lotta Museum is The Story of the Lotta - Always Demand the Most from Yourself. It is an experientially focused exhibit based on the personal experiences of Lottas. Visitors are taken along on a Lotta posting across the country guided by the stories of Lottas who served in medical duties and headquarters. Produced with multimedia this story of the Lotta is combined with photographs that were taken on the same posting. Together, these two narratives - the original voice and the photographs - form a unique and moving story of the Lotta. [3]

\subsection{Making of the blog 'Nostalgic Women'}

After familiarising themselves with life during war-time, the students worked in groups and selected the topics for their blog posts. They were instructed to combine life between 1930-1940, cosmetic chemistry and beauty treatments of that time. They were instructed to focus on war-time beauty, what beauty treatments meant at that time, and what kind of raw materials and natural raw materials were used for cosmetic treatments. To achieve this the students needed to apply their highly specialized knowledge about cosmetic science.

The students were asked to establish what kind of communication is efficient on the internet and in social media. They found that in a good blog post the material should be brief and concise, utilising short videos and interviews and easily made recipes for cosmetic products. All this is taken into 
account in the principles of network communications: briskness, clarity and simplicity. Fig 1. Screen capture from the blog.

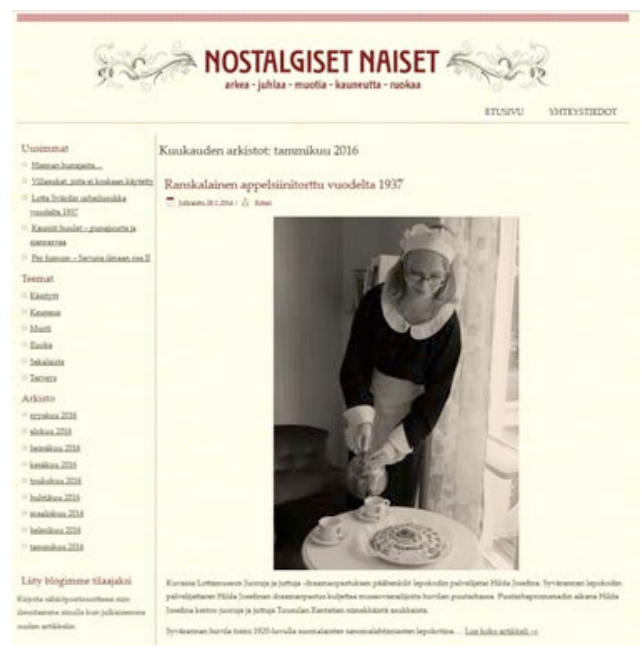

Figure 1. Screen capture from the blog.

The topics of the blog posts varied from information about a natural based raw material and its use, like Beauty from Birch and Dandelion for care of oily skin care, to historical aspects, like The Story of Nivea and Antiperspirants Now and Then. Women have always wanted to make themselves up, Fig.2, despite the surrounding situations, and this was dicussed in the Timeless Beauty Problems and Per Fumum -As Smoke Into Air parts I and II posts.

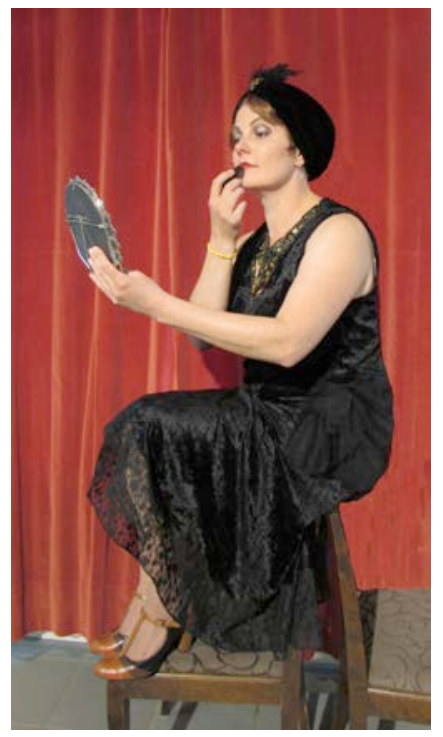

Figure 2. Flapper girl.

The schedule for the blog post releases was planned so, that it followed Finland's four seasons: Blog posts about sunscreens were released in the summer and posts about protecting skin from the frost during the winter. Beautician students from Keuda Vocational College were also involved in the event production. During the project design period, the students from Keuda Vocational College and Laurea University of Applied Sciences met twice.

\section{RESULTS AND DISCUSSION}

The special feature of the project was that an atypical target group, the students, started to create contents based on their own vocational know-how for the already existing target group of the Museum. The content generated by the students has, without exception, received plenty of positive feedback. The blog 'Nostalgic Women' now has a well-established readership. 
One goal was to increase the number of visitors to the Lotta Museum and website. Another goal was to reach new audiences: young women and women interested in beauty. The observed rise in the number of visitors was significant, both in the Museum and the website. After the launch of the blog on 9th January 2016, the pages have been visited 24957 times. $65 \%$ of the followers of the blog came back to read subsequent blog posts. The blog soon found regular and active followers. The blog 'Nostalgic Women' has offered additional visibility for the collection of the museum and a new medium to transmit information about the museum and its thematic. The museum has also reached new visitors and new followers via the blog. In addition, the collaboration with educational institutions has made the Lotta Museum more appealing to young audiences.

Through the content production, the Beauty and Cosmetics students from Laurea University of Applied Sciences were able to present their professional skills to the general public and popularize the science behind cosmetics and cosmetic products. According to the feedback, the students enjoyed working in groups, with historical aspects and concrete materials. They produced videos, made recipes for selfmade cosmetics, tested old beauty tricks and reported them in the blog. Students were able to transform scientific texts into more popularized forms and thereby their knowledge of successful ways of communication increased.

\section{CONCLUSIONS}

The Finnish Association for Museum Education, Pedaali, granted the Annual Award in Museum Pedagogy 2016 to the Nostalgic Women project. The Pedaali's board viewed the project as representing a new approach to engaging audiences and a new way of making museums more accessible. Collaboration with educational institutions has helped to make the Lotta Museum more appealing to young audiences, which are considered to be a challenging target group, and the project has also demonstrated that the past is still relevant today. At the same time, the Lotta Museum has been able to present its themes on a contemporary platform, to provide them with a broader context and open them to wider audiences. The project has made the museum, the Bachelor of beauty and cosmetics degree programme and the cosmetologist sector more widely known. [4]

\section{REFERENCES}

[1] Nostalgic Women, cited 28.9.2016. www.nostalgisetnaiset.fi

[2] Laurea University of Applied Sciences, cited 28.9.2016. https://www.laurea.fi/

[3] Lotta Museum, cited 28.9.2016. http://www.lottamuseo.fi/en/

[4] The Finnish Association for Museum Education, Pedaali, cited 28.9.2016. http://www.pedaali.fi/en 